\title{
How can we better align private security with the public interest? Towards a civilizing model of regulation
}

\author{
Ian Loader \\ Centre for Criminology, University of Oxford, UK \\ \& \\ Adam White \\ School of Law, University of Sheffield, UK
}

\begin{abstract}
How can we better align private security with the public interest? This question has met with two answers in the literature on private security regulation, one seeking to cleanse the market of deviant sellers, the other to communalize the market through the empowerment of buyers. Both models of regulation are premised upon a limited neoclassical economic conception of how market transactions map onto the public interest. This article makes the case for a new model of regulation, one that seeks to civilize private security. Drawing upon the insights of economic sociology, our model regards the market for security as a moral economy in which commodity and noncommodity values jostle and collide. On this basis, we propose a regulatory architecture where buyers and sellers are cast not only as economic actors but also as moral actors, in the process revealing new avenues through which to encompass private security within the democratic promise of security.
\end{abstract}

Keywords: deliberation, economic sociology, private security, public interest, solidarity 


\section{How can we better align private security with the public interest? Towards a civilizing model of regulation}

We think robust policy ideas are most likely to be discovered when we pursue areas of convergence between analyses based on homo economicus and those based on homos sociologicus. (Ayres and Braithwaite 1992, p.51)

The idea that social bonds can be grafted onto economic transactions if conditions are favourable remains to be explored in depth (Hirschman 2013, p.227)

\section{Introduction}

The global market for security services and technologies - which includes static and mobile guarding, intelligence, surveillance, tracking and associated goods designed to protect persons and property in both civil and hostile environments - was valued at $£ 410$ billion in 2012 and is forecast to reach $£ 571$ billion by 2016 (UK Trade \& Investment/Home Office 2014, p.4). ${ }^{1}$ For those willing and able to pay, these commodities offer advantages in terms of value for money, flexibility and expertise, and they often generate positive externalities by contributing to reductions in crime rates (Farrell et al 2011). Yet they are also a cause for concern. Fierce competition results in the proliferation of budget services and technologies which erode the wellbeing and safety of citizens (Button 2008). Unequal buying power not only means that the rich enjoy privileged access to the market but also that security resources are often distributed in inverse relation to risk (Hope 2000). Commodifying security into discrete goods tailored to individual, community and organisational preferences chips away at the trust and solidarity required to guarantee equal protection for all members of society (Loader and Walker 2007). For these reasons the global market for security services and technologies stands in tension with the democratic promise of modern security - the idea that all members of a political community have a stake in, and merit equal consideration when determining, the protective arrangements of that community. As such, this market is a legitimate concern of all citizens whether or not they participate in it - in Dewey's $(1927$, p.13) words, it 'acquires a public capacity'.

For many classical liberals and social democrats, these problems provide sufficient reason for severely curtailing the size and scope of private security. Critics of the industry point in particular to evidence that the market for 'guard labour' has

\footnotetext{
${ }^{1}$ Admittedly, this is a broad definition of private security which glances over many of the nuances in the market. However, it is an appopriate definition for an article which is more concerned with overarching regulatory concepts and principles than it is with finer empirical detail.
} 
expanded most rapidly in societies marked by high levels of inequality (Jayadev and Bowles 2006). They advocate 'inclusive economic and social policies' (Reiner 2010, p.173) which, it is hoped, will reduce the demand for private protection and hence radically restrict or even eradicate the market for security. We have much sympathy with this analysis and its attendant aspirations. We are not, however, convinced that an 'abolitionist' approach to private security is feasible or, in the end, desirable. In our view, the most significant and vexing issues posed by the aforementioned problems are regulatory. With this in mind, we seek to work with - rather than against - the market, focusing on the question: how can we better align private security with the public interest? Our starting point is dissatisfaction with the answers standardly given to this question in the literature on private security regulation.

Two broad models of regulation have dominated this literature: one seeking to cleanse the market, the other to communalize it. Our dissatisfaction arises from the fact that both are predicated on the same neoclassical economic interpretation of how market transactions map onto the public interest. So long as buyers enter into the market of their own volition and agree legally permissible terms and conditions with honourable sellers, no challenge to the public interest is seen to occur. Challenges only arise - and regulatory responses are only needed - when flaws creep into this model of 'good' economic behaviour, for instance where sellers act dishonourably and/or where buyers are unable access the market. The impact of 'normal' market transactions upon other public values and commitments has no necessary bearing on the behaviour of these actors. It is not only assumed, for example, that a security guard stationed inside the perimeter of a gated community will disregard a fellow citizen in distress just a few meters beyond the fence unless his contract requires him to intervene, but also that the contract holder will be satisfied with this course of action. The moral obligations of the guard and the contract holder to their co-citizen are not part of the neoclassical economic picture. For these models, the task of regulation is simply to serve the public interest by ensuring that the market functions efficiently. As Prosser (2006, p.375) puts it: the 'rules limiting the operation of markets are justifiable if they are necessary to correct market failure', they are 'not perceived as representing broader social values quite different from those expressed though markets themselves'.

Our research has led us to an alternative reading of how transactions in the market for security relate to the public interest (see Table 1). While the market for security functions in accordance with neoclassical economic assumptions to a significant degree, it is at the same time shot through with a range of public values and commitments articulated outside the terms and conditions of the contract. We have encountered buyers and sellers who not only acknowledge that security services and technologies impact upon social relations in ways that have discernible and sometimes damaging effects upon non-market goods such as trust and 
solidarity, but who also spontaneously act to mitigate these effects. This suggests that the security market is a contested space in which public and private motivations jostle and collide with each other and where commodities are judged in terms of their perceived effects on a complex conception of the public interest which incorporates not only the prevention of market failure but also the promotion of good citizenship. Our reading, then, accounts for the fact that the aforementioned guard may well ignore his contractual stipulations and respond to the citizen in distress out of a sense of public duty and, furthermore, that the contract holder will approve of this non-contractual course of action. While we appreciate that these observations are rooted in the UK case, this combination of economic and moral agency can certainly be found in other markets too (see: Ocqueteau 1993; Ferret 2004; Gimenez-Salinas 2004; Rigakos and Leung 2006, Löfstrand et al. 2016). Going further, because this relationship between the market and the public interest is an expression of such deep-rooted human behaviour, we hypothesise that it is, in fact, a common feature of the global market for security (though of course more empirical research is required to test this hypothesis). 
Table 1: Research on the 'political economy' or 'moral economy' of private security

\begin{tabular}{|c|c|c|c|c|}
\hline Project & $\begin{array}{l}\text { Data } \\
\text { Collection }\end{array}$ & Methodology & $\begin{array}{l}\text { Main } \\
\text { Outputs }\end{array}$ & Key Findings \\
\hline $\begin{array}{l}\text { Regulating } \\
\text { Private Security }\end{array}$ & $\begin{array}{l}\text { June } 2007 \text { - } \\
\text { July } 2009\end{array}$ & $\begin{array}{l}\text { Semi structured } \\
\text { interviews with: } 11 \\
\text { executives in the } \\
\text { private security } \\
\text { industry; } 31 \text { street level } \\
\text { operators in the private } \\
\text { security industry; } 10 \\
\text { police officers; } 14 \text { civil } \\
\text { servants. All interviews } \\
\text { conducted in the } \\
\text { United Kingdom }\end{array}$ & $\begin{array}{l}\text { White 2010, } \\
\text { 2012, 2014b, } \\
\text { 2016; White and } \\
\text { Gill 2013; Smith } \\
\text { and White } 2014\end{array}$ & $\begin{array}{l}\text { There is a widely held expectation } \\
\text { that security ought to be delivered as } \\
\text { a public good. This expectation limits } \\
\text { opportunities for expansion in the } \\
\text { market for security. Consequently, } \\
\text { private security actors engage in a } \\
\text { variety of legitimation activities } \\
\text { designed to more closely align their } \\
\text { operations with this state-centric } \\
\text { expectation and, by extension, to } \\
\text { open up more opportunities. } \\
\text { Common activities include: using } \\
\text { police-like uniforms, employing ex- } \\
\text { police officers wherever possible and, } \\
\text { most importantly, pursuing ever } \\
\text { greater degrees of statutory } \\
\text { regulation. }\end{array}$ \\
\hline $\begin{array}{l}\text { Consuming } \\
\text { Security }\end{array}$ & $\begin{array}{l}\text { October 2007- } \\
\text { September } \\
2009\end{array}$ & $\begin{array}{l}\text { Semi structured } \\
\text { interviews with: } 28 \\
\text { manufacturers/retailers } \\
\text { of security products; } 8 \\
\text { industry stakeholders; } \\
\text { and } 14 \text { security } \\
\text { managers in public and } \\
\text { private sector } \\
\text { organizations. } 4 \text { group } \\
\text { discussions and } 12 \\
\text { interviews with } \\
\text { individual consumers. } \\
\text { All interviews } \\
\text { conducted in the } \\
\text { United Kingdom }\end{array}$ & $\begin{array}{l}\text { Goold et al. 2013; } \\
\text { Loader et al. } \\
\text { 2014, 2016; } \\
\text { Thumala et al. } \\
\text { 2011, } 2015\end{array}$ & $\begin{array}{l}\text { Markets for security are structured } \\
\text { not only by instrumental calculation } \\
\text { but also by a range of moral } \\
\text { sentiments expressed outside of the } \\
\text { terms of contracts. Sellers frequently } \\
\text { talk about the industry as a 'tainted } \\
\text { trade' and rarely justify their work } \\
\text { with reference to what Boltanski and } \\
\text { Thévenot (2006, ch.6) call 'the market } \\
\text { world'. They also engage in } \\
\text { legitimation work which 'borrows' the } \\
\text { trappings of state authority. Among } \\
\text { buyers, decisions about whether to } \\
\text { purchase security goods (such as GPS } \\
\text { trackers or gated housing) depend on } \\
\text { whether such purchases are thought } \\
\text { to corrode values such as privacy and } \\
\text { trust (in the case of trackers) and } \\
\text { moral and aesthetic ideals of } \\
\text { neighbourhood (in respect of gated } \\
\text { communities). }\end{array}$ \\
\hline $\begin{array}{l}\text { Post-Crisis } \\
\text { Policing and } \\
\text { Public-Private } \\
\text { Partnerships }\end{array}$ & $\begin{array}{l}\text { September } \\
2013 \text { - January } \\
2014\end{array}$ & $\begin{array}{l}\text { Semi structured } \\
\text { interviews with: } 11 \\
\text { police officers/staff; } 9 \\
\text { private security } \\
\text { operators; } 2 \text { civil } \\
\text { servants. All interviews } \\
\text { conducted in the } \\
\text { United Kingdom }\end{array}$ & $\begin{array}{l}\text { White 2014a, } \\
2015\end{array}$ & $\begin{array}{l}\text { Contrary to public perceptions, the } \\
\text { process of outsourcing frontline } \\
\text { policing services to the private } \\
\text { security industry does not equate to a } \\
\text { straightforward marketization of } \\
\text { these services. Instead they become } \\
\text { characterised by a complex blurring of } \\
\text { public good and market logics } \\
\text { distributed across both the police and } \\
\text { private security actors engaged in the } \\
\text { delivery of the frontline service. }\end{array}$ \\
\hline
\end{tabular}


This alternative reading of the relationship between market transactions and the public interest has prompted us to stake out a new position in the field of private security regulation. We defend the position that the goal of regulation should not be limited simply to cleansing the market of dishonourable sellers and/or communalising the market for disempowered buyers, but should also seek to civilize the market for security through the promotion of regulatory space where the noncontractual public values and commitments of both market and non-market actors can be expressed, deliberated upon and (if appropriate) institutionalised. Central to this regulatory ambition is the premise that buyers and sellers can and should be invited into this space not only as recalcitrant economic actors unconcerned about the social consequences of their market behaviour (homo economicus), but also as moral actors with their own non-contractual public values and commitments (homos sociologicus), thereby leading to favourable conditions in which to graft social bonds onto economic transactions. For far too long, private security has been democracy's 'dirty little secret', its character narrowly understood outside academic circles and its impact on society too rarely debated in the public sphere. By recommending the incorporation of this civilizing function into regulatory space, we hope to begin the process of embedding private security within a new 'democratic promise of security' in which the implications of this ubiquitous market can be explored, understood and acted upon. Of course, this model is no magic bullet. Regulatory analysis is a valueladen process guided by particular regulatory goals and constrained by historically contingent regulatory contexts (Prosser 2010, p.19). The civilizing model is neither intrinsically superior to the cleansing and communalizing models nor suited to every regulatory environment. Our argument is simply that any endeavour to better align private security with the public interest is to some extent enriched through consideration of the civilizing model.

As a secondary ambition, we also hope to strengthen the dialogue between the fields of regulatory governance and economic sociology - a dialogue which has become increasingly valuable in recent years as ever more scholars have turned their attention towards the ambitious enterprise of understanding how public, private and third sector actors shape each other's behavior within decentred regulatory space (Hancher and Moran 1989; Black 2002; Sibley 2011). In order to analyse and regulate the activities of buyers and sellers in any sector, it is necessary to explore the extent to which they are motivated not only by economic imperatives but also moral commitments - to view markets not simply as spaces of amoral exchange but as sites for the generation, affirmation and transmission of 'economies of worth' (Boltanski and Thévenot 2006; see also Zelizer 2011; Wherry 2012). In this article, we do precisely this - we draw upon the insights of economic sociology both to reveal economic and moral agency in the market for security and to investigate the regulatory possibilities this agency brings into view. Of course, these dynamics are sector specific. The buying and selling of security services and technologies raises 
different kinds of moral dilemmas compared to, say, the buying and selling of cosmetics tested on laboratory animals or diamonds extracted from conflict zones. Yet to the extent that our analysis serves as a kind of template for investigating the relationship between economic imperatives, moral commitments and regulatory possibilities in other sectors, it has a broader resonance in the field of regulatory governance.

Table 2: Models of regulating private security

\begin{tabular}{|c|c|c|c|}
\hline & Cleansing Model & $\begin{array}{l}\text { Communalizing } \\
\text { Model }\end{array}$ & Civilizing Model \\
\hline Regulatory goal & $\begin{array}{l}\text { Consumer choice; product } \\
\text { quality }\end{array}$ & $\begin{array}{l}\text { Market access; local } \\
\text { capacity-building }\end{array}$ & $\begin{array}{l}\text { Inclusive deliberation; social } \\
\text { solidarity }\end{array}$ \\
\hline \multicolumn{4}{|l|}{ Assumptions } \\
\hline $\begin{array}{l}\text { Conception of } \\
\text { market }\end{array}$ & $\begin{array}{l}\text { Neoclassical economic; } \\
\text { amoral spaces of exchange }\end{array}$ & $\begin{array}{l}\text { Neoclassical economic; } \\
\text { amoral spaces of exchange }\end{array}$ & $\begin{array}{l}\text { Economic sociology; moral } \\
\text { spaces of exchange }\end{array}$ \\
\hline $\begin{array}{l}\text { Conception of public } \\
\text { interest }\end{array}$ & $\begin{array}{l}\text { Realised through market } \\
\text { efficiency and enforcement } \\
\text { of contractual relationships }\end{array}$ & $\begin{array}{l}\text { Realised through market } \\
\text { efficiency and enforcement } \\
\text { of contractual relationships }\end{array}$ & $\begin{array}{l}\text { Realised through public duty } \\
\text { articulated outside of } \\
\text { contractual relationships }\end{array}$ \\
\hline \multicolumn{4}{|l|}{ Analysis } \\
\hline $\begin{array}{l}\text { Problems with } \\
\text { security market }\end{array}$ & $\begin{array}{l}\text { Low standards among sellers } \\
\text { of security services and } \\
\text { technologies; grudge } \\
\text { purchasing. }\end{array}$ & $\begin{array}{l}\text { Unequal purchasing power } \\
\text { among buyers of security } \\
\text { services and technologies; } \\
\text { governance/security } \\
\text { deficits }\end{array}$ & $\begin{array}{l}\text { Social fragmentation in the } \\
\text { democratic polity }\end{array}$ \\
\hline \multicolumn{4}{|l|}{ Solutions } \\
\hline Regulatory targets & Sellers & Buyers & Buyers and sellers \\
\hline $\begin{array}{l}\text { Conception of } \\
\text { regulatory space }\end{array}$ & Centred & Centred and decentred & Centred and decentred \\
\hline $\begin{array}{l}\text { Regulatory } \\
\text { mechanisms }\end{array}$ & $\begin{array}{l}\text { Rules: licensing, standard- } \\
\text { setting, codes of practice, } \\
\text { monitoring }\end{array}$ & $\begin{array}{l}\text { Rules and principles: local } \\
\text { budgets, participation }\end{array}$ & $\begin{array}{l}\text { Principles and rules: } \\
\text { dialogue, delegation and } \\
\text { responsive regulation }\end{array}$ \\
\hline $\begin{array}{l}\text { Relation } \\
\text { to/conception of } \\
\text { democracy }\end{array}$ & $\begin{array}{l}\text { Background; } \\
\text { Representative }\end{array}$ & $\begin{array}{l}\text { Foreground; } \\
\text { Local, participative }\end{array}$ & $\begin{array}{l}\text { Foreground; } \\
\text { deliberative }\end{array}$ \\
\hline $\begin{array}{l}\text { Relation to status } \\
\text { quo }\end{array}$ & Conservative & Critical and reformist & Critical and reformist \\
\hline
\end{tabular}

This constructive project must, however, be preceded by some conceptual mapping and ground-clearing - in itself a valuable exercise since it has rarely been done in this field of research (though see Crawford 2006). As such, the next two sections critically assess the cleansing and communalizing models of private security regulation. In each case, we structure our discussion along three conceptual axes: 
their underlying assumptions regarding the relationship between the market and the public interest; their analysis of why regulation is required; and their regulatory solutions. Following this critical assessment, we map out the central propositions of our civilizing model along the same axes (see Table 2) and offer some initial thoughts on institutional design.

\section{Cleansing the market for security}

The 'cleansing' model - which seeks to rid the security market of deviant sellers so as to better serve the public interest - is the default position in the literature on private security regulation. While this school of thought has no recognised 'founding' figures whose work serves as an obvious point of analytical departure, a small group of scholars have in recent years emerged as a kind of vanguard - namely Mark Button, Tim Prenzler and Rick Sarre (see especially: Button 2008, 2012; Prenzler \& Sarre 2008, 2014). Upon surveying their body of work, what becomes immediately apparent is that they interpret the market for security and its relationship to the public interest through a textbook neoclassical economic lens. So long as buyers enter freely into the market and, following an informed appraisal of the services and technologies on offer, agree legally permissible terms and conditions with honourable sellers, no challenge to the public interest is generally seen to take place, regardless of whether or not the transaction erodes public values and commitments. Non-contractual moral concerns have no place in this model, either as a feature of market failure or as a motivator of human agency.

Problems only enter into the frame when their model of 'good' neoclassical economic behaviour falls apart. Button $(2008,2012)$ notes the issue of buyers entering into the market under conditions of coercion rather than of their own volition - for instance, as a result of the stipulations of an insurance policy. This in turn gives rise to a common phenomenon known as 'grudge' purchasing:

Decisions to purchase security by individuals and organisations are taken for a variety of reasons, but one of the recurring themes in many sub-sectors of the industry is that it is treated as a grudge, a tax on the bottom line, which provides little benefit. As such many will buy the cheapest (Button 2012, p.206).

Under conditions of grudge purchasing, sellers flood the market with budget security services and technologies as they are forced to compete on price rather than quality (see further: Loader et al. 2016). The implications of this race to the bottom are significant, as Button (2008, p.166) explains with reference to the guarding sector: 'Uncompetitive pay and conditions mean security staff are recruited from the bottom end of the market, making poor quality recruits more likely, leading to 
potentially less competent security staff more open to deviant influences'. Expanding upon this line of reasoning, Prenzler and Sarre (2008, pp.266-68) have constructed a 'risk profile' of such deviancy in the market, which includes the following : fraud, incompetence and poor standards, exploitation of staff, corruption, violent malpractice, false arrest and detention, trespass and invasion of privacy, discrimination and harassment, and insider crime. All are clear instances of market failure and threats to the public interest.

Just as there is a consensus on the nature of the problem among these scholars, so too is there broad agreement on how to construct a regulatory solution. Guided by a pragmatic reading of the institutional mechanisms already on offer, Button, Prenzler and Sarre turn in the first instance to traditional state-centred command and control regulation targeted at sellers. From the 1960 s onwards, governments of all political colours have implemented licensing systems 'designed to protect all persons who come into contact with security personnel or who rely on security services in some way', thereby cleansing the market for security of deviant sellers (Prenzler \& Sarre 2008, p.265). Using this observation as a common starting point, these scholars have sought to refine such licensing systems by collating comparative data from around the world and building models of best practice.

The most comprehensive comparative analysis to date has been compiled by Button in the form of the United Nations Office on Drugs and Crime's (UNODC) (2014) Handbook on State Regulation Concerning Civilian Private Security Services and their Contribution to Crime Prevention and Community Safety. By reviewing the content of government licensing systems in 43 countries across Europe, North America, South America, Australasia, Africa and Asia, ${ }^{2}$ the Handbook maps out an array of licensing criteria for both individuals and companies, all designed to cleanse sellers of deviant behaviour and, by extension, to align the market for security with the public interest - summarised in Table 3. Using this (and similar) comparative data, two key models of best practice have come to the fore: Button's (2012) model of 'optimum' regulation, which evolved out of Button and George's (2006) earlier 'comprehensive wide' model; and Prenzler and Sarre's (2014) 'smart' model which builds upon their earlier 'risk-profile' model (Prenzler \& Sarre 2008). The rationale underpinning both of these models is essentially the same: 'to avoid the pitfalls of both under-regulation - manifested in regulatory failure, recurring misconduct and poor standards - and over regulation - manifested in unjustified burdens on

\footnotetext{
2 The 43 countries are as follows (by region). Europe: Belgium, Bulgaria, Denmark, Estonia, Finland, France, Germany, Hungary, Italy, Ireland, the Netherlands, Norway, Poland, Portugal, Russia, Spain, Sweden and the United Kingdom. North America: Canada (British Columbia, Ontario); the United States (California, District of Columbia, Florida, Georgia, Michigan, Ohio, Virginia, Washington State). South America: Belize, Bolivia, Brazil, Chile, Columbia, Costa Rica, El Salvador, Equador, Honduras, Mexico, Panama and Uruguay. Australisia: Australia (New South Wales, Victoria). Africa: Kenya, Mozambique, South Africa, Uganda. Asia: Japan, Israel, Korea, Philippines, Singapore and the United Arab Emerites.
} 
industry, such as excessive licence fees and inflexible employment conditions' (Prenzler \& Sarre 2014, p.875). The regulatory goal, in other words, is to impose just enough tightly-specified rules on sellers to avoid those market failures which are detrimental to the public interest. The only real difference between the models is a slightly different combination of licensing criteria in order to manage this regulatory balance.

Table 3: UNODC Private Security Licensing Criteria

\begin{tabular}{|l|l|l|l|}
\hline Individuals & Training & Companies & Working \\
& & Status & Conditions \\
\hline Status & Knowledge of role & Listing of services & Minimum wage \\
\hline Legal employment status & Knowledge of legislation & Financial viability & Maximum working hours \\
\hline No criminal record & Communication skills & Insurance & Prescribed rest breaks \\
\hline Physical and mental health & Conflict resolution & Legal awareness & Appropriate equipment \\
\hline Residence history & Physical intervention & Quality assurance & Workplace risk analysis \\
\hline Education & Use of force continuum & Authorised uniforms & \\
\hline Literacy & Code of conduct & Registered street address & \\
\hline Identity number & Dress and deportment & Appropriate equipment & \\
\hline Employment history & Customer service skills & Secure data storage & \\
\hline Firearm licence (if armed) & Emergency procedures & Employee records & \\
\hline Fingerprint records & Human rights standards & Reporting procedures & \\
\hline Drug screening & Record keeping & Record keeping & \\
\hline Credit check & $\begin{array}{l}\text { Dealing with (vulnerable) } \\
\text { public }\end{array}$ & $\begin{array}{l}\text { Dealing with (vulnerable) } \\
\text { public }\end{array}$ & \\
\hline & Consequence of failure & Consequence of failure & \\
\hline & Firearms (if applicable) & Firearms (if applicable) & \\
\hline
\end{tabular}

The cleansing model is certainly valuable. Evidence suggests that the process of imposing tightly specified rules on sellers does indeed serve to remove deviant influences from the market (though perhaps not to the degree anticipated by its proponents, see White 2013) - so the pursuit of best practice is worthwhile. Yet the model offers only a partial answer to the question 'how can we better align private security with the public interest?'. To begin with, it focuses on only one side dishonourable sellers - of an already limited interpretation of the relationship between the market for security and the public interest. Not only is the other side of the equation - how the disempowering of buyers leads to distributional inequalities in the market for security - overlooked, but the model's overarching neoclassical economic emphasis seemingly blinds its proponents to the moral economy of security. As a consequence, there is no consideration of the public values and commitments articulated by buyers and sellers outside of the terms and conditions of the contract or how this moral agency might be inscribed into the regulatory 
system through democratic principles. Indeed, democracy is treated as the unexamined background against which regulation takes place, not as an element of the regulatory space through which the market for security is constituted.

Moreover, the model's narrow - or centred - conception of regulatory space means that the state is regarded as the only institution with the capacity to formulate and administer these rules. This status-quo bias blinds the model to other actors and logics of behaviour in regulatory space and limits its reach and ambition. It gives rise to the impression that what the 'best' states currently do to regulate private security is the best for which one can hope - hence the promotion of league tables ranking different national regulatory regimes against each other (see Button 2007). We do not propose that the cleansing model should in any way be jettisoned. But it does need to be supplemented with other models which are founded on a more nuanced understanding of the relationship between the market for security and the public interest and situated in a more expansive conception of regulatory space.

\section{Communalizing the market for security}

The communalizing model - which seeks to empower cash-poor buyers by equalizing access to the market for security - answers these criticisms in a number of respects. Not only does it advance a much more radical conception of regulatory space in which the state is just one of many actors endowed with the capacity to shape the market for security, but it adds new logics of regulatory action through an emphasis on democratic principles as well as legal rules, and brings into frame buyers as targets of regulation (though sellers largely drop out of the regulatory picture). In common with the cleansing model, though, it reproduces neoclassical economic assumptions about the relationship between the market for security and the public interest. Once again, challenges to the public interest are only seen to occur in the form of market failure - even if it is a different dimension of failure related to distributional inequities. The non-contractual moral agency of buyers and (especially) sellers remains for the most part hidden from view. Before proceeding with an evaluation of these analytical features, it should be emphasised that the communalizing model is embedded within a broader conceptualisation of the security landscape known as the 'nodal governance' approach, and it is to this we turn first.

The nodal governance approach is associated with a core group of scholars most prominently David Bayley, Les Johnston, Clifford Shearing, Philip Stenning and Jennifer Wood - whose work in the 1990s and 2000s represented a significant challenge to traditional state-centric or monopolistic understandings of security (Bayley \& Shearing 1996, 2001; Johnston \& Shearing 2003; Shearing 1996, 2006; Shearing \& Wood 2003a/b; Wood \& Shearing 2007). While their objective is to 
explore the complexity and contingency of this increasingly pluralized and fragmented landscape, the key propositions they lay down to do this are simple to articulate. They begin with the empirical observation (drawn from earlier research by Shearing \& Stenning 1981, 1983) that with the post-war growth of non-state security services and technologies, the state no longer dominates the sphere of security as it once did. Using Osborne and Gaebler's (1992) ubiquitous analogy, they repeatedly note that both the 'steering' and 'rowing' of security is now undertaken by a combination of public, private and third sector actors. This demands, they continue, that we redraw the map of the security landscape. 'Centred' maps which presuppose the primacy of state agency - such as those associated with the 'positive state' and the 'regulatory state' (Majone 1997) - should be replaced with 'decentred' maps in which no a priori assumptions are made about the relative influence of state and non-state agency - this is instead a matter for empirical enquiry.

To give decentred maps shape and form, these scholars deploy the conceptual pairing of 'nodes' and 'networks'. Nodes are spaces in which security regimes are assembled around a particular combination of institutions, practices, mentalities, knowledge bases and resources. They are usually (though not necessarily) much smaller than the state - for instance, shopping malls, gated communities, industrial complexes, leisure parks and so on (hence the need to dispose of 'centred' maps) - and they are penetrated by and connected together within a series of networks which transcend state boundaries. On these re-drawn maps, which share a number of commonalities with the post-regulatory state literature (see Crawford 2006), the 'steering' and 'rowing' of security is articulated at the nodal level - hence the term 'nodal governance'.

Alongside these descriptive and explanatory propositions, these scholars advance a complementary normative position: that nodal governance is 'good' for those 'denizens' inhabiting each node. The rationale behind this position is key to the present discussion since it brings the neoclassical economic assumptions of the approach into view. Drawing explicitly on Hayek's (1945) critique of over-centralized political authority and decision-making, they contend that the state lacks both the governing capacity and localised knowledge necessary to meet the complex and wide ranging security needs of individuals and communities. By contrast, the economic laws of supply and demand present individuals and communities with the opportunity to buy security services and technologies directly from sellers whose very survival is dependent upon an ability to meet these needs. As such, the market is regarded as a far more effective (and democratic) mechanism through which to distribute security goods since it enables 'local capacity building'. It is with the introduction of this normative position - and the corresponding diagnosis of problems and recommendation of solutions in the market for security - that the communalizing model of private security regulation begins to take shape. It also 
becomes clear at this stage that it shares with the cleansing model the neoclassical assumption that so long as buyers are free to enter into the security market and agree legally permissible terms and conditions with honourable sellers, no challenge to the public interest is seen to occur.

In contrast to the cleansing model, however, the communalizing model is not blind to problems of distributional inequality. As Bayley and Shearing (1996, p.593) put it:

The pluralizing of policing promises to increase public safety and has already done so in some places. The problem is that pluralizing under market auspices at present does not improve security equally across society. It favours individuals and institutions that are well-to-do.

In other words, cash-rich nodes (e.g., gated communities) are better positioned to take advantage of the market so as to construct security regimes which meet their specific needs - to build local capacity - than are cash-poor nodes (e.g., makeshift townships). Rather than accepting this problem as the natural order of things as neoliberals tend to do, or viewing it as grounds for reasserting a state monopoly as classic liberals and social democrats tend to do, proponents of the communalizing model formulate the issue as follows:

While markets - and the neo-liberal sensibility that supports them - appear to have hastened and deepened the governance deficit, it is not markets so must as inequality of access to purchasing power and budget ownership that is the source of problems (Shearing \& Wood 2003a, p.414).

There is more than an echo in this formulation of the third way ideology of the BlairClinton era in which 'equality of opportunity' trumps 'equality of outcome'. While these scholars do not explicitly theorize 'equality of opportunity' as a public interest, this is precisely what it is within the context of third way ideology: a foundational 'right' of every 'citizen-consumer'. As such, in this model it is unequal access to the market for security among buyers which, more than anything else, compromises the public interest.

Given this diagnosis, it is unsurprising to discover that the corresponding regulatory solution advanced in the communalizing model is also focused on buyers - it is noteworthy that the 'deviant' sellers who loom so large in the cleansing model scarcely merit a mention. The central question is: how can we give buyers in cashpoor nodes equivalent access to the market for security as buyers in cash-rich nodes - that is, how can the market for security be communalized so that it works for poor communities? The answer is to this question is simple: redistribute taxpayer money 
to cash-poor nodes. Bayley and Shearing $(1996$, p.603) develop this proposal as follows:

One way of achieving this would be through block grants to poor communities so that they can participate in the commercial market for security. Not only does this level up access to security, it vests directive authority in the people most affected ... In effect, communities would be given security budgets that they could spend on various mixtures of public and private policing (see also Johnston \& Shearing 2003, pp.156-7).

The proposed transfer of taxpayer money is not, however, without conditions - and it is important to highlight that these conditions bring other dimensions of the public interest into the frame. In expanding the proposal, for instance, Shearing and Wood (2003b) stipulate that for any transfer to go ahead those 'common goods' - which are seen to exist somewhere in the middle of a spectrum bookended by 'public goods' and 'private goods' - produced at the nodal level must be compatible with a broader conception of the public interest: 'to act peacefully (without the threat or use of force), to work within the law, to respect human rights, and to act impartially ... These regulatory requirements ensure that what is done to manage conflict does not abrogate the public interest' (Johnston \& Wood, 2003b pp.220-1; see also Johnston \& Shearing 2003, pp.144-5). So, in their view, there is a delicate balance to be struck between communalizing market access in the public interest and ensuring that the resulting market outcomes remain wedded to other public values and commitments.

This solution, however, has been subject to criticism. As Loader and Walker (2006, pp.177-8) observe, while it engenders a radical devolution of power to the community and market, it also requires the state to collect and redistribute wealth through taxation and to uphold peace, law, human rights and standards of arbitration. It is therefore predicated on the very state agency that the nodal governance approach seeks to analytically deprioritise. In response, this solution has subsequently been revised in line with the mantra 'nodal solutions to nodal problems' (Wood \& Shearing 2007, p.98). Building upon the 'weapons of the weak' literature (Scott 1985; Braithwaite 2004), for instance, Wood and Shearing (2007, pp.101-112) argue that wherever possible nodes should utilise their own 'in-kind' resources rather than 'cash' resources when assembling security regimes so as to reduce dependence on centrally redistributed taxpayer money. They also advocate Gunningham and Grabosky's (1998) 'smart regulation' agenda, which emphasises the role of both state and non-state actors (e.g., NGOs) in holding these regimes accountable to broader public values and commitments (Wood \& Shearing 2007, pp.132-141). These revisions add noteworthy new dimensions to the communalizing model, illustrating how the problem of inequitable market access can at least in part 
be reframed as a problem of self-sufficiency, and how the solutions to both problems can to some extent be further decentred though the use of non-state actors.

It is also important to emphasise that these analytical propositions are more than abstract discussion. They have to an extent been informed by, and borne out in, real-life examples of nodal security governance. Given the model's radical orientation, it is unsurprising to discover that there are relatively few instances of communalizing ideals being played out in practice (certainly compared to the more orthodox cleansing model). Yet where this has happened, key nodal governance scholars have often been present, observing and influencing the course of events. As Shearing and Froestad (2010) explain, the first moment of practical application in what they regard as 'an iterative process of research-theory-engagement-researchtheory-engagement', was during the late 1980s in a partnership with the Metropolitan Toronto Housing Authority. Guided by the advice of Shearing and his colleagues, staff and tenants in a range of residential complexes were allocated 'open security budgets' which they could use to determine their own localised security arrangements. As Shearing and Froestad (2010, p.107) reflect, in accordance with localised preferences 'some of the nodes included in this nodal mix had been "occupationalised" as security resources - for example, contract security firms - while others had not', choosing instead to enhance security by investing resources in social capital projects. Either way, the distinctive feature of these regimes is that they were assembled at the nodal level through bottom-up decisionmaking processes and devolved budgets.

In more recent years, the attention of these scholars has shifted to Zwelethemba, a long-neglected South African settlement of 20,000 individuals living in formal and informal housing. Drawing upon cash investments from the international donor community and, more latterly, the South African government as well as in-kind community resources, Shearing and colleagues have contributed towards the establishment of Zwelethemba Peace Committees which administer forward-looking regimes of localised dispute resolution (Shearing and Froestad 2010, pp.108-115). While monetary payments are made to Peace Committee administrators, the process is less 'occupationalized' than the Toronto example and therefore reflects a shift from market (cash) to non-market (in kind) security solutions. This project has proved successful to the extent that Shearing and his colleagues now herald the 'Zwelethemba Model' as the flagship example of communalizing ideals being realised in practice.

In both theory and practice, then, the communalizing model stretches the regulatory imagination far beyond the centred picture developed in the cleansing model - though in a way that is complementary to, and able to incorporate, this branch of the literature on private security regulation. It also carves out more space for public values and commitments to play a role in the regulatory process by 
foregrounding local democratic participation as a vital part of what is required to make security markets work for poor communities. For these reasons, the model makes a key contribution to the question of how to better align private security with the public interest. Yet even in its revised form the model for the most part cleaves to a distinctly neoclassical economic view of the connections between the market and the public interest. While the motivations of buyers may be articulated through democratic participation, the public values and commitments of sellers and other actors with a stake in the market are underexplored and of secondary importance. There is no sense of a market shot through with moral agency articulated outside the terms and conditions of the contract (cf. Loader et al. 2014).

\section{Civilizing the market for security}

The regulatory model we propose builds upon, rather than jettisons, the cleansing and communalizing models. The forms of market failure these models are seeking to correct - the proliferation of deviant sellers and the disempowerment of cash-poor buyers - do indeed stand in tension with the public interest and demand some kind of regulatory response. As a consequence of their common neoclassical economic roots, however, these models also miss a great deal. They fail to appreciate how a successfully functioning market for security poses material and symbolic risks to the egalitarian project of protecting all citizens from private violence' (Sklansky 2006, p.98). The market is not simply a space in which individuals, communities and organizations are free to satisfy their demands for protection through contractual arrangements. It a form of private power whose scale, distribution and activities are necessarily implicated in, and may challenge and erode, the democratic social order (Loader \& Walker 2007). Furthermore, these models underplay the significance of the deeply held public values and commitments bound up in market transactions. Not only is the non-contractual moral agency of buyers and sellers a central feature of how the market for security functions at present, but this agency also has the potential to at least partly ameliorate these risks to the democratic social order. It is with this 'thicker' conception of the relationship between the market for security and the public interest in mind that we propose a new regulatory model focused upon the goal of civilizing private security.

The basic design of our model is at once pragmatic and idealist. It is pragmatic in the sense that it does not attempt to rebuild the regulatory landscape from scratch. Rather, it seeks to engage with a number of institutions already endowed with regulatory capacity in the market for security, including (but not limited to) public regulators, police forces and trade associations. It is important to emphasise that these institutions are almost without exception constituted at the national level and can be found right across the globe. As such, in terms of 'working with what we have', our model is necessarily rather national in orientation - though 
its underlying principles and logics are not spatially bound - and have extensive geographical reach. The efficiency, effectiveness and legitimacy of these institutions is highly variable, however, making some easier to work with than others. Our model is idealistic in the sense that it seeks to modify and enhance the practices of these institutions in line with three ideal-type regulatory propositions, which draw inspiration from Ayres and Braithwaite's (1992) ideas of 'responsive regulation'. First, in addition to administrating licencing regimes, public regulators should steer stakeholder practices in line with the principles of 'inclusive deliberation' and 'social solidarity'. Second, the task of operationalizing these principles should as far as possible be delegated 'downwards' to public and private bodies such as police forces and trade associations. Third, if such delegation proves unsuccessful, the public regulator should be given the power to transform (elements of) these principles into statutory rules, essentially giving them the same legal status as their licensing regimes. We expand on each of these propositions below.

We have already introduced public regulators in our analysis of the cleansing model. For present purposes, two characteristics of these bodies are noteworthy. First, they are ubiquitous: as the UNODC (2014) Handbook on State Regulation Concerning Civilian Private Security Services and their Contribution to Crime Prevention and Community Safety illustrates, it is possible to find these bodies in every continent except Antarctica. Second, given this global presence, they are under-utilised as regulators. As things stand, their function is simply to minimise deviant behaviour in the selling community through various forms of standardsetting, licensing and compliance monitoring - an unremarkable but admittedly vital task. In the civilizing model, we envisage an expanded role for public regulators. They should be given the additional task of administrating a publicly constituted space in which buyers, sellers and other actors with a stake in the market for security - such as police forces, trade associations, unions, civil rights organisations, and those unfairly targeted or displaced by the market - could routinely convene in order to share and explore the tensions between economic imperatives and moral considerations. In so doing, the public regulator would, in effect, become a democratic anchor in a system of regulatory pluralism (Loader \& Walker 2007).

Regulators should administer these stakeholder practices in order to advance two principles: inclusive deliberation and social solidarity. Before expanding upon the content of these principles, it is first necessary to add a brief note about what we mean by the term 'principles'. In contrast to rules, principles 'enjoin the pursuit or achievement of a value, a goal or an outcome without specifying the actions required to do so' (Braithwaite \& Braithwaite 1995, p.307). By guiding action in ways that under-specify the precise means through which to give effect to them, they have several potential advantages. Realising their promise requires that principles are given force in ways that render them operative in the work of the range of state and non-state actors who make up regulatory space. Embedded in these settings, 
principles invite and mutually orient all actors who possess a stake in or are affected by the market for security to determine how best to give practical effect to their animating values. They also create opportunities for market actors to become participants in, rather than simply the object of, regulatory activity. In these ways, principles become a platform for creativity and experimentalism in interpreting what they require.

What though of the content of our principles? By 'inclusive deliberation' we refer to the process of sustaining an open dialogue in which all parties whose everyday lives are affected by the market for security are given the opportunity to explore how the market impacts upon their public values and commitments, in the process bringing into civic consciousness the contested aspects of security that at present remain relatively absent from public scrutiny (see, generally, Habermas 2000, Part V; Sass and Dryzek 2014; and also Black 2000, 2001). By 'social solidarity' we refer to the process of fostering connections between 'irresponsible' market transactions and the 'responsibility' members of a political community have towards each other's security (MacGilvray 2011, p.197). This means attending closely to iniquitous and damaging social patterning in the market and finding ways of compensating for the security deficits it generates. By administrating a publicly constituted space in line with these principles, the public regulator would contribute towards the important process of positioning non-contractual public values and commitments at the centre of regulatory space, both as a measure of market failure and as a motivator of human agency.

Of course, talking is one thing, making sure something happens on the ground is quite another. For this reason, following each round of dialogue, the public regulator (in its role as convenor) should delegate the responsibility for addressing security deficits to institutions whose influence reaches down to market activities at street level. The process of delegation should be mediated through memoranda of understanding (MoUs) signed by all those institutions involved in a particular regulatory response (which would not necessarily include the public regulator). MoUs are particularly suited to such principles-based, non-binding modes of delegation between a range of actors, for as Cherney et al $(2006$, p.378) note (in a similar policing and security context), they are:

mechanisms that activate the necessary processes and practices through which 'responsibilization' is orchestrated ... they are not legally binding contracts nor are they enforceable, but they do create the conditions under which both public and private sector bodies work to police the interface between legitimate commercial activities and illicit trade.

In addition to drawing up clear and concise MoUs, it is also necessary to choose appropriate delegates. While a range of institutions could fulfil this role - and the 
appropriateness of different institutions would depend on local context - two in particular stand out: police forces and industry trade associations.

Even in today's pluralised security landscape, police forces are not only present in every national security sector, but they are more often than not the dominant institution. In addition to their role as repositories of legitimate force, they are also the historic guardians of the public interest with a mission which is ideologically defined not by a particularistic client mandate (and orientation to specific order) but by a requirement to offer protection to all (and hence an orientation to general order) (see Marenin 1982). To the extent that this mission is realised - and too often it is not, falling prey to partisan interests - sellers in the market for security tend to exist in the shadow of the police and aspire to be policelike. As Van Steden et al. (2013, p.13) put it: 'private security guards put police officers on something of a pedestal. The traditional image of police officers as "guardians of justice" and the "sword of the state" lives strongly in the minds of their private colleagues - in some ways even more so than among police officers themselves.' This gives (well respected) police forces significant power to communicate the importance of public values and commitments to the industry. Police chiefs in such forces should filter the content of relevant MoUs down their rank hierarchies so that officers on the ground could use them as a guide for cultivating the moral agency of sellers in the market for security and nurture their aspiration to perform their sectional contractual obligations in ways that promote trust and solidarity. Police chiefs should also exercise their power as consumers to procure goods and services from the industry in line with MoU directives (Independent Police Commission 2013, pp.177-179). In the civilizing model, police forces are viewed not as top-down regulators of private security (cf. Innes 2004), but as one side of a public-private partnership which rests upon, and therefore deepens, the principles of inclusive deliberation and social solidarity.

Just as police forces are ever present in the contemporary security landscape, so too are private security industry trade associations. Not only do these associations champion the economic interests of their members, but they also promote public values and commitments - usually in the guise of professional standards and/or corporate social responsibility - through a range of 'hard' and 'soft' regulatory mechanisms. Hard mechanisms most commonly take the form of mandatory codes of practice which advance, among other things, principles of human rights. Soft mechanisms include status building events such as awards ceremonies which celebrate conceptions of the public interest beyond a narrow client-defined relationship - the British Security Industry Associations Annual Awards, for example, has a prize for 'outstanding act', whose recipients are lauded for feats of heroic rescue, emergency first-aid, and public safety interventions that 
far exceed contractually stipulated duties. ${ }^{3}$ Against this backdrop, trade association executives should translate the content of relevant MoUs into these hard and soft regulatory mechanisms in order to project the principles of inclusive deliberation and social solidarity to sellers on the ground. At its best this process can begin to generate broader recognition of the non-commodity values in play when security is bought and sold. At worst, it may mean that sellers are civilized - and held to account - by their own hypocrisy (Elster 1997, p.14).

At this juncture, it is necessary to answer two interrelated questions. How should we monitor these processes of delegation? What enforcement strategies should we deploy if they are not functioning properly? To begin with, those inspectors responsible for monitoring the licensing system should take on the additional task of tracking the extent to which the MoUs are being operationalised. When checking compliance with licensing rules, they should ask sellers to evidence that MoU content is being incorporated in the their standard operating procedures. If the inspectors are dissatisfied with this evidence, they should make suggestions for improvements (they cannot make stronger demands because MoUs are not legally binding). Given the extent of the non-contractual moral agency already articulated by buyers and sellers in the market for security, we believe such persuasion tactics would achieve a great deal. However, it would be naïve to think that these processes would be free of regulatory gaming, capture or straightforward noncompliance, especially in a market dominated by hugely powerful multinational corporations. It is for this reason we propose complementary enforcement strategies in the centre.

If the operationalization of these principles continues to prove unsuccessful, inspectors should notify the board of the public regulator. In order to remedy the problem, the board should invoke a series of escalating enforcement powers as per the responsive regulation enforcement pyramid (Ayres and Braithwaite 1992, p.35). At the bottom of the pyramid would be persuasion, whereby the board would appeal to the moral agency of the uncooperative party, thereby reinforcing the ground work already done by the inspectors. In the middle of the pyramid would be naming and shaming, whereby the public regulator would broadcast how the uncooperative party is damaging public values and commitments in the market for security - an especially potent tactic given that it is already widely regarded as a 'tainted trade' (Thumala et al. 2011). Above this would be the power to fine the company or close it down. At the apex of the pyramid would be the transformation of these principles into statutory rules, essentially giving them the same legal status

\footnotetext{
${ }^{3}$ See http://www.bsia.co.uk/aboutbsia/news/OXE6CQ302931 and http://www.bsia.co.uk/SecurityPersonnel-Award-winners-2012-announced
} 
as the licensing regimes. As such, the ultimate sanction would be 'de-commodifying' (Vail 2010) security markets where they are judged to be 'noxious' (Satz 2010). As Aryes and Braithwaite (1992, p.19) note in setting out their 'benign big gun' model of responsive regulation, 'the bigger and more various are the sticks, the greater the success regulators will achieve by speaking softly'. In other words, sellers would be so concerned about an area of their business activity being de-commodified that they would become be more amenable to the power of persuasion.

\section{Conclusion}

Regulation does not take place in a political, philosophical or moral vacuum. Regulators are necessarily guided by an ethic of some kind, even if they cannot put it into words. The choice of ethic is a supremely political matter which should be publicly debated and democratically determined, not left to technocrats or bureaucrats. (Marquand 2014, pp.71-2)

We have sought to outline and defend a new regulatory model - and accompanying political ethic - for better aligning private security with the public interest. The model we propose offers no magic bullet. There are no objective criteria against which to claim the civilizing model's intrinsic superiority over the other two models we have described and assessed. The above discussion has proceeded from a specific set of regulatory goals - inclusive deliberation and social solidarity - and there is room for debate over this analytical starting point. Furthermore, the model is historically contingent. At least three variables need to be in place for this model of regulation to work: i) a critical mass of non-contractual moral agency in the market for security; ii) (relatively) efficient, effective and legitimate public regulators, police forces and trade associations or equivalent institutions; iii) a set of stakeholders willing to engage in dialogue about the tensions between economic imperatives and moral considerations. These conditions are by no means universal, but neither are they especially rare and we believe the model is sufficiently pragmatic to be viable in many jurisdictions. Of course, even where the civilizing model is viable, there is no guarantee it will have its intended effect on the market for security. Like any other model of regulation, it is susceptible to problems of regulatory gaming, capture and non-compliance - though we have indicated how these risks can be mitigated. However, given what is at stake - nothing less than renewing the democratic promise of security under conditions of market and nonmarket provision - we think that the civilizing model is an enterprise worth pursuing. 


\section{Acknowledgements}

Earlier iterations of this paper were presented at the National Law University Delhi; the Centre for the Study of Law and Society, University of California Berkeley, and the Department of Law, London School of Economics. We wish to thank all those who participated in the discussions that ensued. We are also grateful to Daniel Fitzpatrick, Tony Prosser, Clifford Shearing, Neil Walker, Lucia Zedner and five anonymous journal reviewers for their helpful comments. All errors remain our own. Adam White would also like to thank the Gerda Henkel Foundation for its generous financial support during the writing of this article.

\section{References}

Ayres I and Braithwaite J (1992) Responsive Regulation: Transcending the Deregulation Debate. Oxford University Press, Oxford.

Ayling J, Grabowsky P, Shearing C (2009) Lengthening the Arm of the Law: Enhancing Police Resources in the Twenty-First Century. Cambridge University Press, Cambridge, UK.

Bayley D, Shearing C (1996) The Future of Policing. Law \& Society Review, 30(3), 585606.

Bayley D, Shearing C (2001) The New Structure of Policing: Description, Conceptualization and Research Agenda. National Institute of Justice, Washington.

Black J (2000) Proceduralizing Regulation: Part I. Oxford Journal of Legal Studies, 20(4), 597-614.

Black J (2001) Proceduralizing Regulation: Part II. Oxford Journal of Legal Studies, 21(1), 33-58.

Black J (2002) Critical Reflections on Regulation. Australian Journal of Legal Philosophy 27(1), 1-37.

Boltanski L, Thévenot, L (2006) On Justification: Economies of Worth. Princeton University Press, Princeton, N.J.

Braithwaite, J (2002) Rules and Principles: A Theory of Legal Certainty. Australian Journal of Legal Philosophy, 27(1), 47-82.

Braithwaite J (2004) Methods of Power for Development: Weapons of the Weak, Weapons of the Strong. Michigan Journal of International Law, 26(1), 297330 .

Braithwaite J, Braithwaite, V (1995) The Politics of Legalism: Rules versus Standards in Nursing-Home Regulation. Social \& Legal Studies, 4, 307-341.

Button M (2008) Doing Security: Critical Reflections and An Agenda For Change. Palgrave Macmillan, Basingstoke.

Button M (2012) Optimizing Security through Effective Regulation: Lessons From Around the Globe. In Prenzler T (ed) Policing and Security in Practice, 204220. Palgrave Macmillan, Basingstoke. 
Button M, George B (2006) Regulation of Private Security: Models for Analysis. In Gill M. (ed) The Handbook of Security, 563-585. Palgrave Macmillan, Basingstoke. Cherney A, O'Reilly J and Grabosky P (2006) Networks and Meta-regulation:

Strategies Aimed at Governing Illicit Synthetic Drugs. Policing and Society 16(4), 370-385.

Crawford A (2006) Networked Governance and the Post-Regulatory State: Steering, Rowing and Anchoring the Provision of Policing and Security. Theoretical Criminology 10(4), 449-479.

Dewey J (1927) The Public and its Problems. Shallow Press, Athens, US.

Farrell, G., Tseloni, A., Mailley, J. and Tilley, N. (2011) The Crime Drop and the Security Thesis. Journal of Research in Crime and Delinquency, 48(2), 147175.

Ferret J (2004) The State, Policing and "Old Continental Europe": Managing the Local/National Tension. Policing and Society, 14(1), 49-65

George B, Button M (1997) Private Security Industry Regulation: Lessons From Abroad for the United Kingdom. International Journal of Risk, Security and Crime Prevention 2(3), 187-200.

Gimenez-Salinas A (2004) New Approaches Regarding Public/Private Security. Policing and Society, 14(2), 128-174.

Goold B, Loader I, Thumala A (2013) The Banality of Security: The Curious Case of Surveillance Cameras. British Journal of Criminology, 53(6), 977-996.

Gunningham N, Grabosky P (1998) Smart Regulation: Designing Environmental Policy. Oxford University Press, Oxford.

Habermas, J (2000) The Inclusion of the Other. Cambridge, Mass.: MIT Press. Hancher L, Moran M (1989) Organizing Regulatory Space. In Hancher L, Moran M (eds) Capitalism, Culture and Economic Regulation, 271-299. Oxford University Press, Oxford.

Hayek F von (1945/2001) The Road to Serfdom. Routledge, London. Hirschman A (2013) Rival Views of Market Society. In Adelman J (ed) The Essential Hirschman, 214-247. Princeton University Press, Princeton, N.J.

Hope T (2000) Inequality and the Clubbing of Private Security. In Hope T and Sparks R (eds) Crime, Risk and Insecurity, 83-106. London: Routledge.

Independent Police Commission (2013) Policing for a Better Britain; available at:

http://independentpolicecommission.org.uk/uploads/37d80308-be23-9684054d-e4958bb9d518.pdf

Innes M (2004) Reinventing Tradition: Reassurance, Neighbourhood Security and Policing. Criminology \& Criminal Justice, 4(2), 151-171.

Jayadev A, Bowles S (2006) Guard Labour. Journal of Development Economics, 79, 328-348.

Johnston L, Shearing C (2003) Governing Security: Explorations in Policing and Justice. Routledge, London. 
Loader I, Goold B, Thumala A (2014) The Moral Economy of Security. Theoretical Criminology, 18(4), 469-488.

Loader I, Goold B, Thumala A (2016) Grudge Spending: The Interplay between Markets and Culture in the Purchase of Security. The Sociological Review 66, DOI: $10.1111 / 1467-954 X .12329$.

Loader I, Walker N (2006) Necessary Virtues: The Legitimate Place of the State in the Production of Security. In Wood J, Dupont B (eds.) Democracy, Society and the Governance of Security, 165-195. Cambridge University Press, Cambridge, UK.

Loader I, Walker N (2007) Civilizing Security. Cambridge University Press, Cambridge, UK.

Löfstrand C Hansen, Loftus, B and Loader I (2016) Doing 'Dirty Work': Stigma and Esteem in the Private Security Industry. European Journal of Criminology, 12 (in press).

MacGilvray, E (2011) The Invention of Market Freedom. Cambridge University Press, Cambridge, UK.

Majone G (1997) From the Positive to the Regulatory State: Causes and Consequences of Changes in the Mode of Governance. Journal of Public Policy, 17(2), 139-167.

Marenin, O (1982) Parking Tickets and Class Repression: The Concept of Policing in Critical Theories of Criminal Justice. Contemporary Crises, 6, 241-66.

Marquand, D (2014) Mammon's Kingdom: An Essay on Britain, Now. Allen Lane, London.

Ocqueteau F (1993) Legitimation of the Private Security Sector in France. European Journal on Criminal Policy and Research, 1(4), 108-122.

Osborne D, Gaebler T (1992) Reinventing Government: How the Entrepreneurial Spirit is Transforming Government. Adison Wesley, Mass.

Prenzler T, Sarre R (2008) Developing a Risk Profile and Model Regulatory System for the Security Industry. Security Journal, 21(4), 264-277.

Prenzler T, Sarre R (2014) Regulation. In Gill M (ed.) Handbook of Security, 857-879. Palgrave Macmillan, Basingstoke.

Prosser T (2006) Regulation and Social Solidarity. Journal of Law \& Society, 33(3), 364-387.

Prosser T (2010) The Regulatory Enterprise: Government, Regulation, and Legitimacy. Oxford University Press, Oxford.

Reiner R (2010) New Theories of Policing: A Social Democratic Critque. In Downe D, Hobbs R and Newburn T (eds) The Eternal Recurrence of Crime and Control, 142-175. Oxford University Press, Oxford.

Rigakos G Leung C (2006) Canada. In Jones T and Newburn T (eds) Plural Policing: $A$ Comparative Perspective, 126-138. Routledge, Basingstoke. 
Sandel M (2012) What Money Can't Buy: The Moral Limits of Markets. Allen Lane, New York.

Sass, J Dryzek, J (2014) Deliberative Cultures. Political Theory 42(1), 3-25.

Satz D (2010) Why Some Things Should not be for Sale: The Moral Limits of Markets.

Oxford University Press, Oxford.

Scott J (1985) Weapons of the Weak: Everyday Forms of Peasant Resistance. Yale University Press, New Haven.

Sen A (1977) Rational Fools: A Critique of the Behavioural Foundations of Economic Theory. Philosophy and Public Affairs, 6(4), 317-344.

Shearing C (1996) Reinventing Policing: Policing as Governance. In Marenin O (ed)

Policing Change, Changing Police: International Perspectives, 285-305.

Garland, New York.

Shearing C (2006) Reflections on the Refusal to Acknowledge Private Governments. In Wood J, Dupont B (ed.) Democracy, Society and the Governance of Security, 11-32. Cambridge University Press, Cambridge.

Shearing C Stenning P (1981) Modern Private Security: Its Growth and Implications. Crime and Justice 3, 193-245.

Shearing C Stenning P (1983) Private Security: Implications for Social Control. Social Problems 30(5), 493-506.

Shearing C Wood J (2003a) Nodal Governance, Democracy and the New Denizens. Journal of Law \& Society 30(3), 400-419.

Shearing C Wood J (2003b) Governing Security for Common Goods. International Journal of the Sociology of Law 31(3), 205-225.

Shearing C and Froestad J (2010) Nodal Governance and the Zwelethemba Model. In Quirk H, Seddon T and Smith G (eds) Regulation and Criminal Justice: Innovations in Policy and Research, 103-133. Cambridge University Press, Cambridge.

Silbey S (2011) The Sociological Citizen: Pragmatic and Relational Regulation in Law and Organizations. Regulation \& Governance 5(1), 1-13.

Sklansky D (2006) Private Police and Democracy. University of California Law Review, 46: 89-105.

Thumala A, Goold B, Loader I (2011) A Tainted Trade? Moral Ambivalence and Legitimation Work in the Private Security Industry. British Journal of Sociology, 62(2), 283-303.

Thumala A, Goold, B, Loader I (2015) Tracking Devices: On the Reception of a Novel Security Good. Criminology \& Criminal Justice, 15(1), 3-22.

United Kingdom Trade \& Industry/Home Office (2014) Increasing our Security Exports: A New Government Approach. London.

United Nations Office on Drugs and Crime (2014) State Regulation concerning Civilian Private Security Services and their Contribution to Crime Prevention and Community Safety; available at: 
http://www.unodc.org/documents/justice-and-prison-

reform/crimeprevention/Ebook0.pdf

Vail J (2010) Decommodification and Egalitarian Political Economy. Politics \& Society, 38(3), 310-346.

Van Steden R, Van der Wal Z, Lasthuizen K (2013) Overlapping Values, Mutual

Prejudices: Empirical Research into the Ethos of Police Officers and Private Security Guards. Administration \& Society, 47(3), 220-243.

Wherry F (2012) The Culture of Markets. Polity, Cambridge.

White A (2010) The Politics of Private Security: Regulation, Reform and ReLegitimation. Palgrave Macmillan, Basingstoke.

White A (2012) The New Political Economy of Private Security. Theoretical Criminology 16(1), 85-101.

White A (2013) The Impact of the Private Security Industry Act 2001. Security Journal, doi: 10.1057/sj.2012.53.

White A (2014a) Post-Crisis Policing and Public-Private Partnerships: The Case of Lincolnshire Police and G4S. British Journal of Criminology 54(6), 1002-1022.

White A (2014b) Beyond the Regulatory Gaze? Corporate Security, (In)visibility and the Modern State. In Lippert R, Walby K (eds) Corporate Security in the $21^{\text {st }}$ Century, 39-55. Palgrave Macmillan, Basingstoke.

White A (2015) The Politics of Police 'Privatization': A Multiple Streams Approach. Criminology and Criminal Justice, 15(3), 283-299.

White A (2016) Private Security and the Politics of Accountability. In Lister S, Rowe, M (eds) Accountability of Policing. Routledge, London, 172-191.

White A, Gill M (2013) The Transformation of Policing: From Ratios to Rationalities. British Journal of Criminology 53(1), 74-93.

Wood J, Shearing C (2007) Imagining Security. Willan, Cullompton.

Zelizer V (2011) Economic Lives: How Culture Shapes the Economy. Princeton University Press, Princeton. 